\title{
地理的イメージにおける概念図式 \\ EFFECTS OF COGNITIVE SCHEMA ON GEOGRAPHICAL URBAN IMAGE
}

\author{
青木義次*, 朴鍾薰**, 大佛俊 泰*** \\ Yoshitsugu AOKI, Jonghoon PARK and Toshihiro. OSARAGI
}

\begin{abstract}
It is important in the studies on urban image to discuss not only the perceptible objects itself but also the cognitive schemata figured in our minds.

We can imagine the geographical structure of cities although the objects can not be seen directly. This fact suggests that we have a-kind of cognitive schema for the geographical urban image. As an example, we made surveys on our geographical image of the loop lines of stations in Tokyo, Osaka and Seoul. The results show us that our geographical image of loop lines is transfigured to the very simple circular shape with the effects of the cognitive schema.
\end{abstract}

Keywords: cognitive schema, loop line, geographical image, urban image, transfigure of image

認識図式，環状線，地理的イメージ，都市イメージイメージ変形

1.はじめに

K.リンチの研究"'以来，今までの都市イメージに関 する研究は，直接知覚できる物的対象の特性がわれわれ のイメージ形成にいかに影響を及ぼすのかという視点か ら視賞対象としての都市について多く論じられてきた。 こうした研究の成果は，都市や地域の物的環境要素の整 備・改善計画に役立ってきたといえる。

一方，われわれは，直接知覚できない都市構成要素に 対しても，ある種のイメージを持っている。たとえば， 大都市全体の形状とか地下鉄の路線形状に関して，漠然 とした認識を持っている。三條"2は，”わかりやすさ”の 面からこの問題に接近している。，本研究での基本的な関 心事は，直接知覚不可能な対象に対するこうした理解は どのようになされているのかという点にある。とくに， 都市における位置・距離・方向等に関するイメージは， われわれの生活と密接な関係を持っているからである。 以下では，都市要素間の位置関係や距離関倸についての イメージを「地理的イメージ」と呼び，このイメージの
一端を明らかにしたい。

若干突飛な発想であるが，夜空の星の配置はランダム に近く，工学的に星の配置情報を記述したとしたら膨大 なものとなるが，われわれは，それらを見慣れた形やよ く知っている形になぞらえて星座として簡単に理解して いる。本研究のアイディアは，この星座の例のように， よく知られた形になぞらえて都市の見えない空間構造を 理解しているのではないかという仮説から出発している。

\section{2. 地理的イメージ形成に関する仮説と分析手続き}

一般に，都市を構成する要素は，次の三者に分けて捉 えられることが多い。すなわち，主要施設やランドマー クなどの点的要素, 幹線道路などの線的要素, そして, 面的広がりを持った大きな公園などの面的要素である。 われわれは，こうした都市構成要素間の架間的関保をた えず参照しながら都市内で活動していると言える。 本研究では，都市の地理的関倸を理解する上で重要な 本稿は，文献 3)・文献 8）をもとに修正・加筆したものである。

* 東京工業大学工学部建築学科 教授・工博

** 新菱冷熱工業株式会社・工修

*** 東京工業大学工学部建築学科 助手. 工修
Prof., Dept. of Architecture, Faculty of Engineering, Tokyo Institute of Technology, Dr. Eng.

Shinryo Co. Ltd., M: Eng.

Research Assoc., Dept, of Architecture, Faculty of Engineering, Tokyo Institute of Technology, M. Eng. 
役割を担っていると思われる都心部の主要鉄道路線を分 析対象としている。鉄道路線について言えば，われわれ は点的要素である各駅の位置をイメージすることで，そ れらを連結した線的要素である路線形態をイメージし，

逆に，路線形態をイメージすることで駅の位置をイメ一 汭していると言える。本研究では，鉄道駅 (点的要素) の位置に関する調查結果をもとに検討しているが，これ は同時に，路線形態 (線的要素) に関するイメージ分析 でもあるとも言える。

駅のひとつひとつは直接見ることはできても，その全 体像（各駅の位置関俰）は見ることはできない。しかし， われわれはその路線形態についてもあるイメージを持っ ている。この地理的イメージは，それまでの鉄道利用の 経験や，人からの伝聞，または，ガイドブック等にある 路線図や地図をもとに形成されている可能性がある。い ずれにしても，それまでに獲得したあらゆる情報を駆使 して，自分にとって一番わかりやすいように理解・記憶 しているであろう。

都市骨格である路線形状を理解する際, 先の星座の例 での「よく知られた形」に相当するものは何であるかが 問題である。この「よく知られた形」を本論文では『概 念図式』と呼ぶことにしたい。星座の場合は，神話や生 活に密着した動物などの形がみられた。しかし，星座が 命名された時代と比べると，われわれは，幾何図形とい う概念を持っており，これを自由にイメージすることが できる。以下で分析する環状線やその中央を通る路線に 関して言えば，円や直線という形を，よく知られた形と して利用しているとも考えられる。つまり，神話や生活 の場に見られる「もの」の形ではなく，既に抽象化され た「幾何図形」の形になぞらえて理解しているというの が, 本研究の仮説である。

この主張の妥当性を確認するため, 環状線とその中央 を結ぶ路線形態をもつ東京の山手線，大阪の環状線，ソ ウル市 2 号線を対象として選び, 環状部分が円に近く理 解されていること，中央直線状の路線がより直線的に理 解されることを, イメージマップ（スケッチマップ）を 用いた分析で明らかにしたい。

また，星座の理解が, 神話や生活に密着したものの形 になぞらえてなされていたとすれば，文化的な枠組みの 影響は必須であると言わざるを得ない。たとえは，北斗 七星は，熊とみる文化も构とみる文化もある。一方，も しも幾何図形の形になぞらえているのであれは，文化的 枠組みの影響は比較的少ないと考えることができる。

この点を確認するため，上記のソウル市 2 号線を対象 に，日本人と韓国人の二つの被験者グループでの差異を 調へ，有意な差異が見出せないこと，すなわち，文化的枠 組みの影䉕が少なく，概念図式としては幾何図形のよう な普遍的なものが利用されているということを示したい。
3. 調查方法とイメージマップ

\section{1 地理的イメージ調査の概要}

同じ環状構造を持つ三つの環状線（東京の山手線, 大 阪の大阪環状線，韓国ソウル市の環状 2 号線）を調查・ 分析対象とし，これらについて，各駅の位置関俰がごの ように理解されているのかをイメージマップによって調 査した。単純な駅名の記入ミスなどによって有効サンプ ル数が堿ってしまうことが危惧されたので，本調查では， 環状線の各駅名を正しい順序で提示した（表 1 参照）。 また，記入紙の大きさ等が影響しないように，方向性の ない大きな紙に描いてもらった。さらに，調査時には， 次のことを，文章と口頭により被験者に指示した。すな わち，1)本調查は，鉄道駅の位置関俰がどのように認識 されているかを調查することで，居住者の都市空間認識 の仕方を求めようとするものであること。2)この結果は， 今後の都市計画のための基礎情報となりうること。3)近 くの駅だけでなく，全体の位置関係にも注意を払いなが ら，できるだけ正確に描くこと。4)一度描いた駅でも， 自分のイメージに合わない場合には，積極的に修正しな がら描くこと。5)与えた紙に収まるように注意すること。 6)駅の位置を点で，線路は線で表現すること。7)全く知 らない駅は記入せずに，駅名リスト（表 1）の番号に○ 印を記入すること等である。

各調查についての詳細は以下のとおりであり，被験者 の具体的なプロフィールを表 2 に示してある ${ }^{6)}$ 。

(1)山手線 : 山手線とその内側の中央線・総武線を含めた

表1 卧名りスト

\begin{tabular}{|c|c|c|c|}
\hline \multicolumn{3}{|c|}{ 山手泉 } & 中央·維武線 \\
\hline $\begin{aligned} 1 & \text { 東京 } \\
2 & \text { 有楽町 } \\
3 & \text { 新楛 } \\
4 & \text { 浜松町 } \\
5 & \text { 田町 } \\
6 & \text { 品川 } \\
7 & \text { 大崎 } \\
8 & \text { 五反田 } \\
9 & \text { 目黑 } \\
10 & \text { 恵比寿 }\end{aligned}$ & 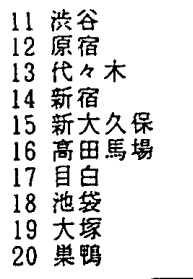 & 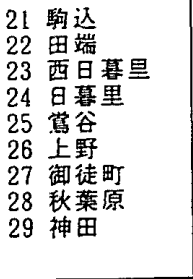 & 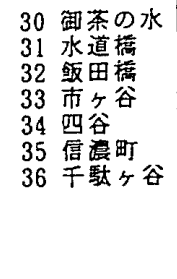 \\
\hline \multicolumn{3}{|c|}{ 大假環汱總 } & 勿堂筋泉 \\
\hline 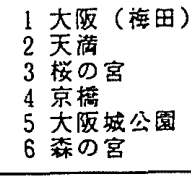 & 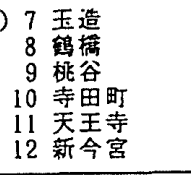 & $\begin{array}{l}13 \text { 芦原棓 } \\
14 \text { 大正 } \\
15 \text { 并町 } \\
16 \text { 西杂条 } \\
17 \text { 野田 } \\
18 \text { 福島 }\end{array}$ & 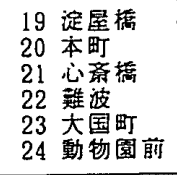 \\
\hline \multicolumn{3}{|c|}{ ソウル市 2 号签 } & 4 号線 \\
\hline 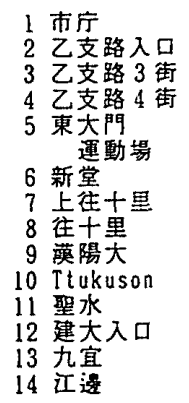 & 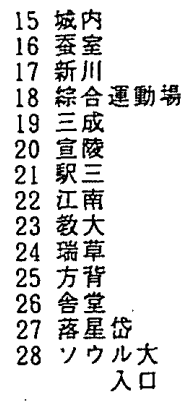 & $\begin{array}{l}29 \text { 奉天 } \\
30 \text { 新林 } \\
31 \text { 新大方 } \\
32 \text { 九老工国 } \\
33 \text { 大林 } \\
34 \text { 新道林 } \\
35 \text { 文來 } \\
36 \text { 永登浦區庁 } \\
37 \text { 堂山 } \\
38 \text { 合并 } \\
39 \text { 弘大入口 } \\
40 \text { 新村 } \\
41 \text { 梨大入口 } \\
42 \text { Ahyon } \\
43 \text { 忠正路 }\end{array}$ & 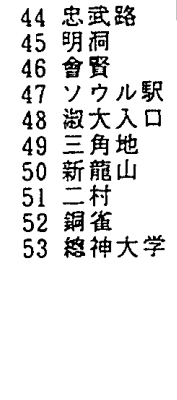 \\
\hline
\end{tabular}


36駅を対象とし，52人の被験者から各駅についての地理 的イメージを得た（調查期間は 1987 年 3 月〜 4 月）。 (2)大阪環状線：大阪環状線および内側の地下鉄御堂筋線 を含めた24駅を対象とし，46人の被駼者から地理的イメ 一ジを得た（調查期間は1990年 8 月）。

(3)ソウル市 2 号線：ソウル市 2 号線および内側の 4 号線 を含む53駅を対象とし，ソウル市在住の韓国人 60 人と日 本人 32 人から地理的イメージを得た（調查期間は 1991 年 8 月)。

この調査では，数を限定した歌の位置関係だけについ て調べていることから，修正を繰り返しながら丁豊に描 いてもらっているにもかかわらず，街路のイメージマッ プを描くときよりも，極めて短時間で描くことができた。 そこで, 駅の数は非常に多いが, 地理的イメージの抽出 にイメージマップを用いてもよいものと判断した。

路線形態の認識の程度は，鉄道の利用経験にも依存し ている可能性がある。しかし，あらかじめ行った予備分 析の結果からは，描かれたイメージマップと利用経験と の間には関連性は認められなかった7”。そこで，本研究 では，鉄道利用の経験との関連性については，詳しく議 論しないこととした。また，居住暦との関係についても 同様に調查したが，両者には強い関連性は認められなか った ${ }^{8 \cdot)}$ 。

被験者の描くイメージマップの大きさには個人による ばらつきがあるので，採用したイメージマップには図 1 に示すような基準化を施した。すなわち，(1)実際の各駅 の位置から求めた重心と，イメージマップに描かれた各 駅の位置から求めた重心とを重ね合わせ，(2)実際の駅と イメージマップ上の同一駅との距離自乗和が最小となる ように，イメージマップに回転と拡大・縮小の変換を施 した

以下での「地理的イメージ」とは，上記のような基準 化を施して得られた各被験者の環状線の地理的イメージ を意味することとする。

\section{2 イメージマップと值線距離評価}

地理的イメージ抽出の一方法として知られるイメージ マップは，紙面の大きさなどの制約から，とくに周辺部 でイメージマップが歪んでしまう恐れがある。そこで, 本調查でのイメージマップの信頼性確認を次のように行 った9)。すなわち，ソウル市内の知名度の高い9駅につ いて，各駅の位置を紙面上に記してもらうイメージマッ プによる万法と，全ての駅の間の直線距離を記入しても らう直線距離評価法"゙によよって地理的イメージの抽出 を行い，両者を比較検討した（被験者は上記のソウル市 在住の計 $92 人) 。$ 後者については, 求めた各駅間の直線 距離をもとに多次元尺度構成法(ALSCAL)を用いて 2 次元 マップを作成した。図 2 は，実際の駅の位置、イメージ マップから得られた駅の位置, 直線距離評価法から得ら
表 2 、被験者の属性

\begin{tabular}{|c|c|c|c|c|c|}
\hline \multicolumn{2}{|c|}{ (师位 : 人) } & \multirow{2}{*}{ 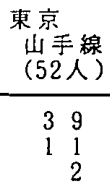 } & \multirow{2}{*}{ 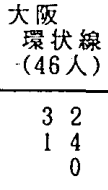 } & \multicolumn{2}{|c|}{$\begin{array}{ll}\text { ソウル } & \text { 号楾 } \\
\text { 韓国人 } & \text { 日本人 } \\
(60 人) & (32 人) \\
\end{array}$} \\
\hline 別 & $\begin{array}{ll}\text { 男 } & \text { 性 } \\
\text { 女 } & \text { 性 } \\
\text { 不 } & \text { 明 }\end{array}$ & & & $\begin{array}{ll}3 & 8 \\
2 & 2 \\
& 0\end{array}$ & $\begin{array}{ll}2 & 0 \\
1 & 2 \\
& 0\end{array}$ \\
\hline 嘎 & 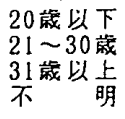 & $\begin{array}{rr}2 & 5 \\
2 & 3 \\
2 \\
2 \\
\\
\end{array}$ & $\begin{array}{rl}2 & 3 \\
1 & 0 \\
3 \\
3 \\
0\end{array}$ & $\begin{array}{ll} & 0 \\
4 & 5 \\
1 & 5 \\
& 0\end{array}$ & $\begin{array}{ll} & 0 \\
1 & 0 \\
2 & 2 \\
& 0\end{array}$ \\
\hline 居 & $\begin{array}{l}0 \sim 4 \text { 年 } \\
5 \sim 10 \text { 年 } \\
.11 \sim 20 \text { 年 } \\
21 \text { 年以卡 } \\
\text { 明 }\end{array}$ & $\begin{array}{r}25 \\
6 \\
6 \\
1 \quad 2 \\
3\end{array}$ & $\begin{array}{ll} & 1 \\
& 3 \\
2 & 9 \\
1 & 2 \\
& 1\end{array}$ & $\begin{array}{ll} & 5 \\
1 & 0 \\
2 & 0 \\
2 & 5 \\
& 0\end{array}$ & $\begin{array}{ll}3 & 0 \\
2 & 0 \\
& 0 \\
& 0 \\
& 0\end{array}$ \\
\hline 噌 & $\begin{array}{l}\text { 高校生 } \\
\text { 荟生学 } \\
\text { 素 婦 } \\
\text { 明 }\end{array}$ & $\begin{array}{r}0 \\
48 \\
2 \\
0 \\
2 \\
2\end{array}$ & $\begin{array}{rr}3 & 3 \\
5 \\
6 \\
2 \\
2 \\
0\end{array}$ & $\begin{array}{ll} & 0 \\
3 & 5 \\
2 & 0 \\
& 0 \\
& \\
& 5\end{array}$ & $\begin{array}{ll} & 0 \\
& 0 \\
2 & 0 \\
1 & 2 \\
& 0\end{array}$ \\
\hline $\begin{array}{l}\text { 環 } \\
\text { 線 } \\
\text { 利 } \\
\text { 用 } \\
\text { 犾 }\end{array}$ & $\begin{array}{l}\text { 通動通学 } \\
\text { に利用 } \\
\text { 買物遊し周 } \\
\text { に利用 } \\
\text { お放利用 } \\
\text { 不しない }\end{array}$ & $\begin{array}{rr}2 & 1 \\
2 & 6 \\
& 3\end{array}$ & $\begin{array}{r}30 \\
4\end{array}$ & 調査せず & 調全せず \\
\hline 住 & 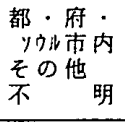 & $\begin{array}{ll}2 & 9 \\
2 & 1 \\
& 2\end{array}$ & $\begin{array}{r}44 \\
0 \\
2 \\
\end{array}$ & $\begin{array}{r}60 \\
0 \\
0 \\
\end{array}$ & $\begin{array}{r}32 \\
0 \\
0 \\
\end{array}$ \\
\hline
\end{tabular}

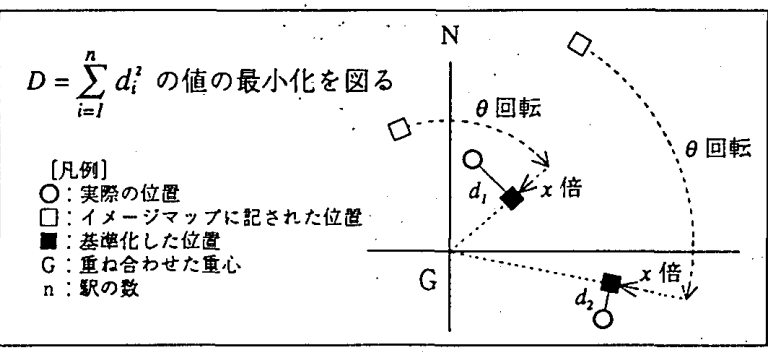

図 1 規染化の手順

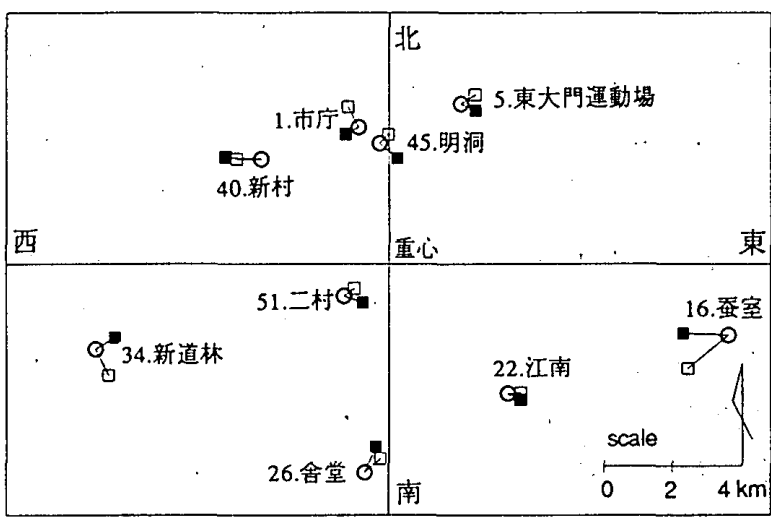

[凡例] ○：実際の位置田:イメージマップよろ駅の位置 口: 直線距離評洒法による駅の位置

図 2 イメージマップと直線距離㲅侹法との比校

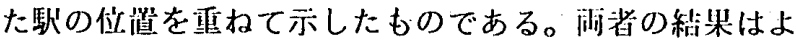
く一致し，照念さ机たような大きな西は生じてていないと 言える。 

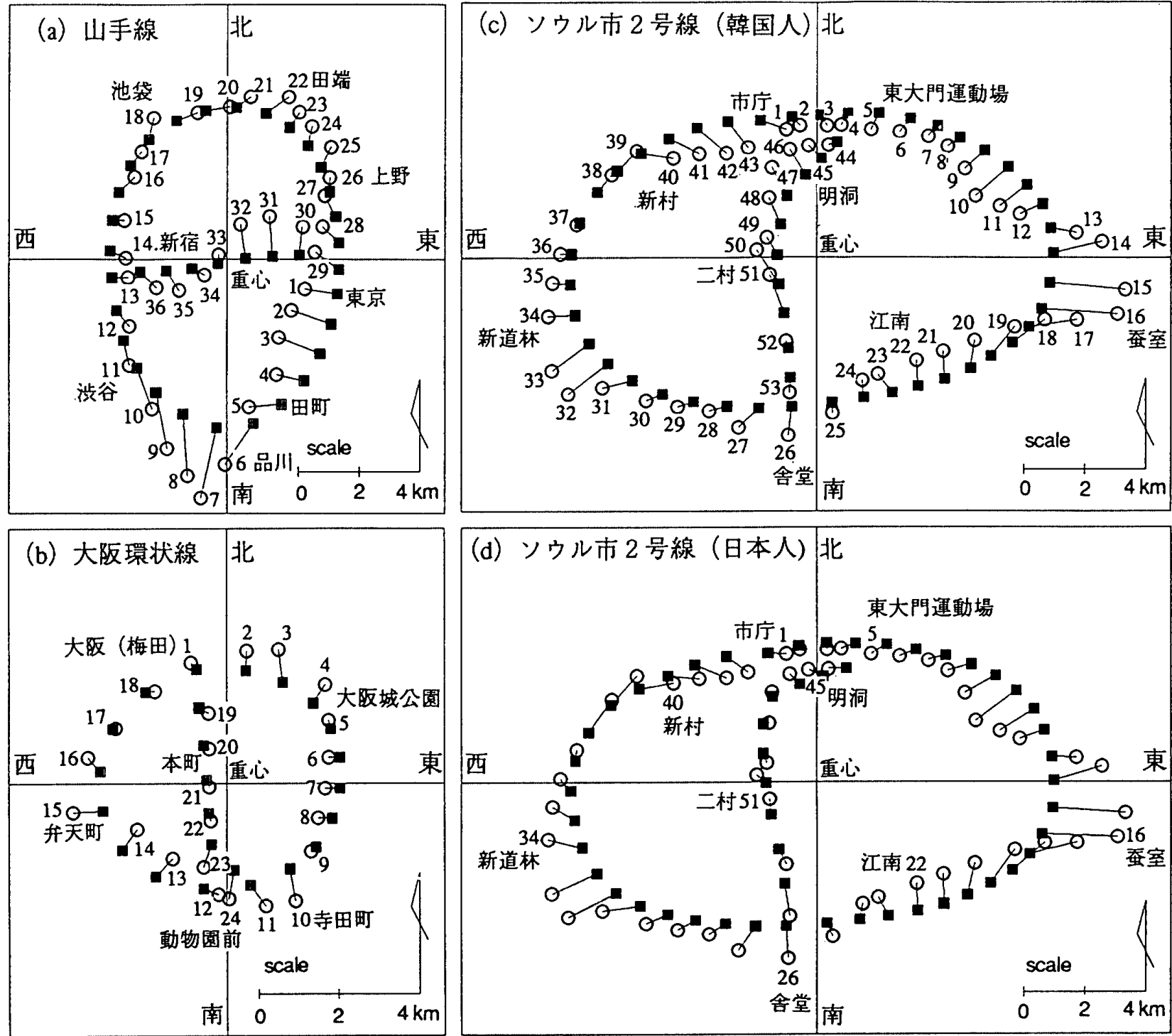

[凡例] $\bigcirc$ :実際の位置

: イメージ上の位置

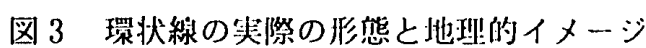

\section{4. 環状線の認識図式}

4. 1 イメージ像からの検証

各駅の実際の位置とイメージ上の位置 (各被験者の地 理的イメージの平均) を示したものが図 3 である。まず, 図 3 (a)の山手線の結果を見ると，その形態は実際の形状 に見られる凹凸がなくなり，かなり単純な円環状の形状 として理解されていることがわかる。また，環状線内部 の路線は直線により近い形状として理解されていると言 える。この事実は，われわれの仮説と一致している傾向 であると言える。

さらに，この饭説の妥当性を確認するため，対象をか えて，大阪環状線に対する分析を行った。その結果を図 3 (b)に示す。これを見ても, 同様の円状の地理的イメ一 ジとなっている。また，「1. 大阪（梅田）」から南への びる地下鉄御堂筋線は，実際には環状線の外側にそって 「24. 動物園前」駅を経由し「11. 天王寺」へ至るが，
イメージ上では環状線の内部から直接「11. 天王寺」へ 接続している。すなわち，「24．動物園前」駅は環状線 の内部に位置するものとイメージされ，地理的イメージ は位置的な变形だけでなくトポロジー的な变形までも受 けている。この事実は，円と直線といった単純な図式に なぞらえて理解しているということを裏付けるものと理 解することができる。

次に，文化的染組みの影響をみるため，文化的な背景 や習慣，居住歴の異なるソウル市在住の韓国人と日本人 に対し，同様の調査を行った。両国民のソウル市 2 号線 に対する地理的イメージを求めたものが図 $3(\mathrm{c})$ ，(d)に示 してある。ここでも同様に，環状線の形態は実際よりも かなり単純な円状の形として認識されており，仮説と一 致した事実となっている。しかも，日本人（ソウル市居 住歴は平均 2 年) の地理的イメージは韓国人のそれと酷 似しており，ほとんど差異は認められない。都市内居住 
歴や文化的背景の違いによる地理的イメージの顕著な差 異は見られず，上記の結果と合わせて，対象として選ん だ路線に関して言えば，円と直線という幾何図形になぞ らえて都市空間を認識しているという主張は，妥当性の あるものと考えることができる。

\section{2 真円度による仮説検証}

以上で求めた環状線の地理的イメージは，円状の単純 な形態であった。しかし，これは各被験者の地理的イメ 一ジを平均したため円い形態となったとも考えられる。 すなわち，各個人の地理的イメージは，それほど円に近 くないという疑いも残る。そこで，固人レベルで検証す るため, 次のような指標值 (真円度 $\tau$ ) を求め, 各被験 者の地理的イメージが実際の形㮩よりも円に近いことを 検証した。この真円度は，次式によって定義されここの 值が1に近いほど，より円に近い形態であることを示す 指標である。

$$
\tau=2 \sqrt{\pi \mathrm{S}} / \mathrm{L}
$$

ただし，S : 対象図形の面積，L : 対象図形の周長 図 4 kは，各被験者の地理的イメージの真円度の分布 を示してある。実際の環状線の真円度（図中の、印）と 比較すると，ほとんど全員の地理的イメージの真円度は, 実際よりも大きな值となっている。すなわち，各被験者 の地理的イメージは実際の形態よりも，より円に近い形 態となっており，われわれの主張は，各個人のレベルで も妥当なものと言える。

\section{3 地理的イメージの変形構造}

以下では，直接知賞できない都市構成要素に対して， われわれが地理的イメージを形成する際に，円や直線と いった概念図式を利用しているということを，地理的イ メージの変形（実際の形状と地理的イメージとの派離を このように本文では呼びたい）の仕方から分析しておき たい。

变形の構造を理解するため, 多少複雑になるが，以下 のような分析手続きを取る。

図 5 (a)に示すように，重心から実際の歌の位置へ向か うべクトルを入，実際の駅の位置からイメージ上の駅の 位置へ向かうベクトルをルとする。さらに，ベクトル入， $\mu$ が東西軸正方向となす角度を $\alpha, \beta$ として，この角度 $\alpha$ ， $\beta$ の関係から地理的イメージ変形構造の特性を調べる。 すなわち，図5(b)のように，もともと棈円に近い路線形 態が，円形の図式になぞらえて理解されていれば， $\alpha, \beta$ から求まる各点は直線 L上に位置することになる。また， 局所的な区間において平行移動の変形が生じていれば図 5 (c)のようなグラフとなる。結果を図 6 に示してある。

山手線（図6(a)）に関しては，その地理的イメージの 変形は，棈円が円に近づく变形であると言える。すなわ ち，もともと楕円に近い形態上にあった山手線の各駅の 位置は円周上近くの位置にイメージされており，円とい
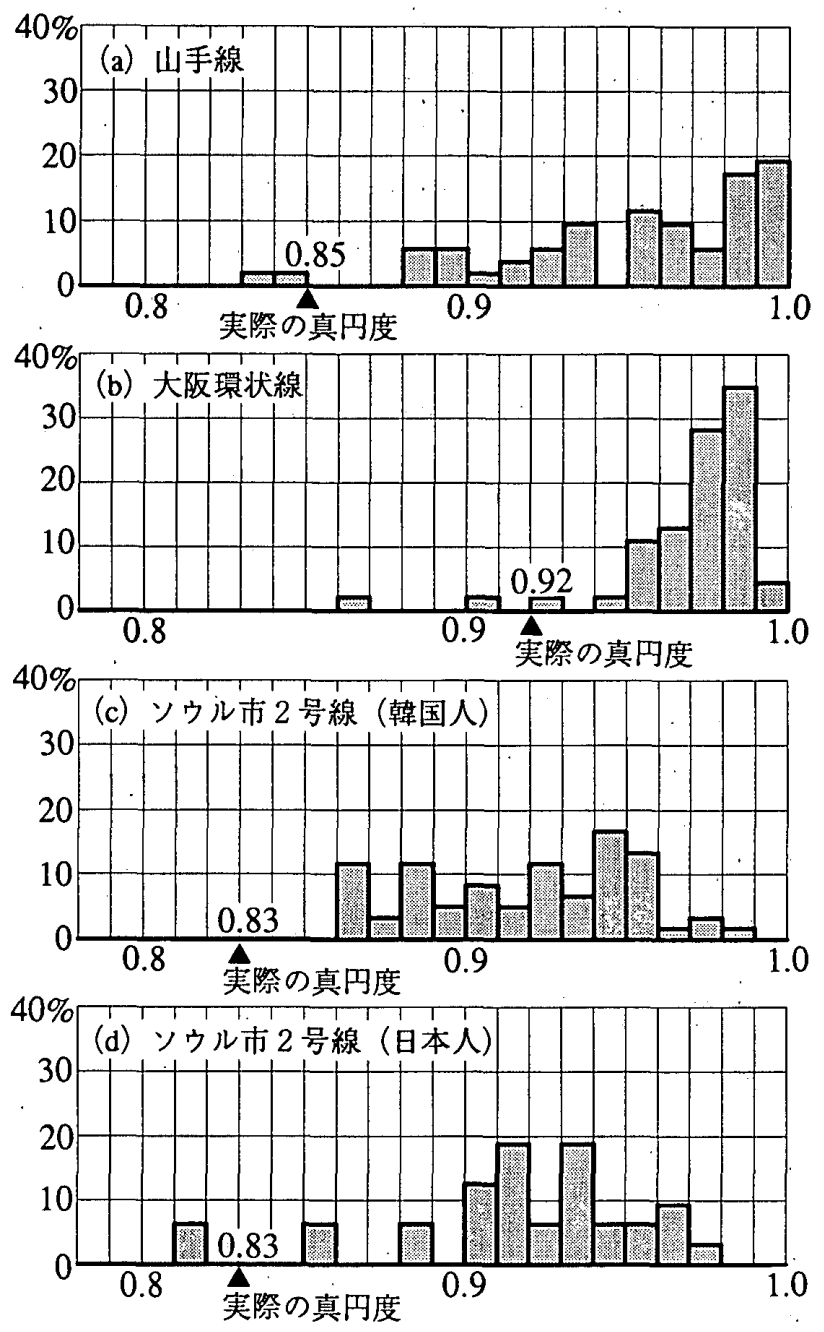

図4 真円度の分布

う概念図式をわれわれが利用していることを示している。 しかし，実際の形態が，棈円に近い形態から涐離し，直 線的になっている『1. 東京』〜 85. 田町』の区間では， $\beta$ の值が $\alpha$ に関わらず横ばいとなっており，局所的には 平行移動の変形もなされていることが分かる。このこと は，東京〜田町間において特殊なイメージ変形がなされ たと言うよりも，全体として円になぞらえて認識してい る結果（図 3 (a)参照)，現実の形態が楕円上にない東京〜 田町間は，楕円が円に近づく変形とは異なるイメージ変 形として計測されてしまったと考えられる。

大阪環状線 (図 6 (b))については, 山手線と比較すると, もともとその路線形態は円に近い。しかし，布置された 点は直線し付近に分布しており，より円に近い円環上に 各駅はイメージされている。この事実も同様に，円とい う概念図式になぞらえているという主張に一致する。

一方, ソウル市 2 号線（図6(c)，(d)）に関しては，全 体としては，円に近づく変形をしているものの前者ほど はっきりした傾向は観察されない（ソウル市 2 号線は，

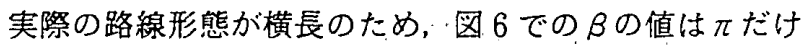
位相がずれている）。これは，実際の. 2 号線の形態が幾 


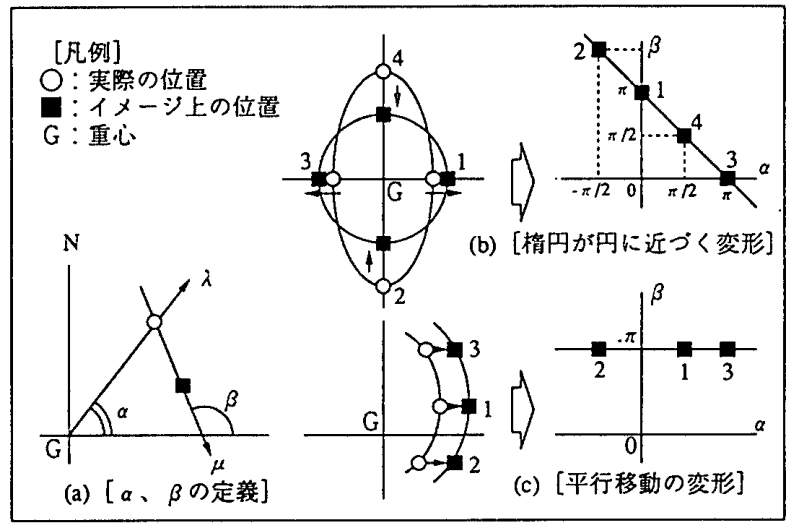

図 5 イメージ澹形構造の概念図
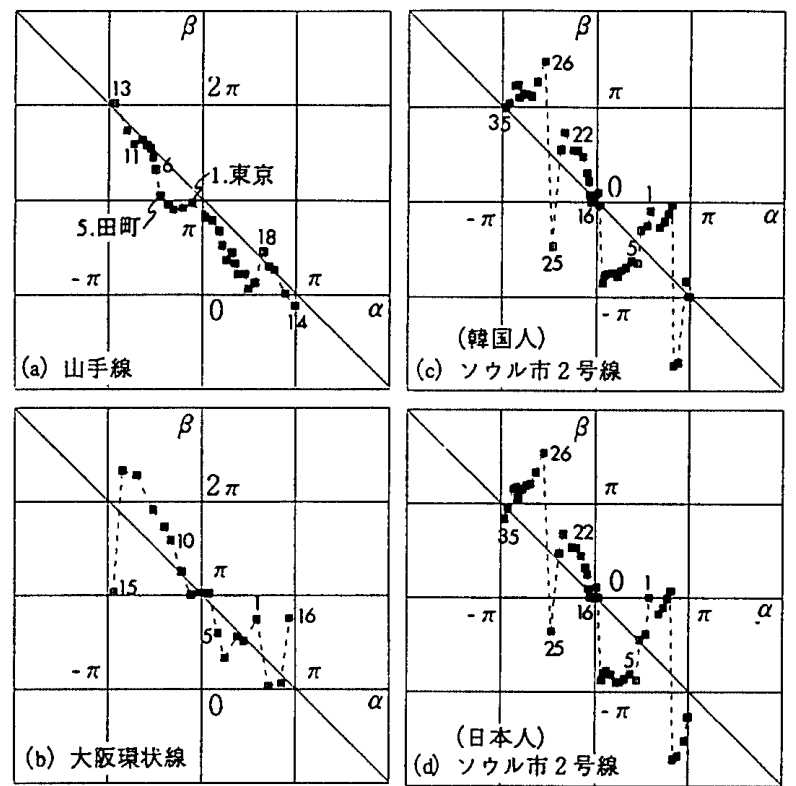

図 6 地理的イメージの変形構造

分いびっであることが原因している可能性もある。

以上の変形構造を分析した結果においても，円という 概念図式になぞらえているという主張は妥当性を持って いると考えられる。しかし，東京山手線やソウル市 2 号 線には，これと異なる局所的な変形も見られ，われわれ の主張は大局的な形状の理解についてのみ妥当であると いう可能性は充分考えられる。

\section{5. 結語}

本研究では，直接知覚できない都市構成要素の位置関 倸に関して，われわれがどのように地理的イメージを形 成しているのかについて検討した。具体的には，都市の 基本骨格となるような環状の鉄道路線（山手線・大阪環 状線・ソウル市 2 号線）について，その地理的イメージ が，円や直線という幾何図形になぞらえて理解されるこ とを論じた。すなわち,

(1)路線形態を単純な幾何图形になぞらえて，単純化して 理解している。環状線は「円」図式のもとで，また，そ
の内部をとおる路線は「直線」図式のもとで理解してい る。

(2)さらに，この図式による理解構造は，居住歴や文化的 な背景の差異に依存した傾向は見いだせない。

以上の結果を総合すると，われわれは，都市空間内の 複雑な位置関保す単純な概念図式にあてはめて理解して おり，その概念図式は，ここで調查分析した環状の鉄道 路線に限って言えは，文化的な枠組みに比較的影響され ない幾何図形が用いられていると主張できる。しかし， どのような概念図式が利用されるかは，対象に依存する と考えられ，他の都市構成要素について言えば，文化的 枠組みの影響が見られる可能性がある。

本研究で得られた結果を, 直ぐに都市空間認識の一般 論にそのままつなげることには困難はあるが，都市計画 上での問題とのかかわりを明確化する意味で次のように 主張したい。すなわち, 都市の居住者は, 都市を実際の 形状の通り理解しているのではなく，概念図式を介して 理解しており，実際に都市計画的観点から合理的な施設 配置や動線計画がなされていたとしても，人々はそれと 異なる位置関保や経路形状をイメージしていることがあ るということである。すなわち，実際と地理的イメージ のこうした殷離を前提として，計画がなされるべきであ ることを示している。また，本研究で分析した鉄道路線 のような形状は，文化的染組みにあまり依存しないこと から、こうした対象に限定すれば，ここで得られた地理 的イメージの非離問題に関する知識は異なる文化におい ても有用であると言える。しかし，本研究で成しえなか った他の都市要素に関しては，依然として文化的枠組み の影響が考えられることから，以上の主張の一層の強化 は今後の課題である。

さらに具体的な問題としては, こうした実際とイメー シの非離が，三條 ${ }^{2)}$ の指摘するように都市のわかりやす さにも関わり，場合によっては生死に関わる可能性もあ $ろ^{5)}$ 。避㒕誘導や道路骠識といった都市内地理的情報の 提供に際しては，単に実態を正確に伝えるだけでなく， また，漂識などの物的対象そのものに工夫を凝らすだけ でなく、こうしたわれわれの都市空間認識の特性を十分 考虑すべきである。

\section{謝辞}

本研究での調查においては，多くの方々にこ協力を頂き ました。ここに感謝の意を表します。特に，調査・分析 においてこ尽力頂きました，篗崎健一氏（伊東豊雄建築 設計事務所），竹林正彦氏（日本設計）をはじめ，青木 研究室の皆嵄に感謝いたします。尚，本研究は文部省科 学研究費一般研究 (C)〔課題番号: 03650489, 平成 3 〜 5 年度)の一部として行ったものである。 


\section{【註】}

1) 文献 1) 参照。

2) 文献 2) 参照。

3 ）この規準化の方法では，駅間の相対的方向，相対的距離な どの相対的位置関倸は完全に保存される。しかし，例えば， 回転移動を行うので「新宿が南, 品川が東の方に位置して いる」と言ったような，被験者の方位感覚のずれなどの絶 対的な方位に関するイメージ変形の情報は捨象されてしま j。

4) 文献11), pp. 162〜168 を参照。

5）文献 9)，10）を参照。

6) 今回の調查には広くて大きな机を要したため街頭調查等の 形式は取れず; そのため，調查毎に被駼者は調查実施者の 知り合いなどを中心にある程度偏ったものとなった。しか し，後述するように，どの調査結果においても同粎の傾向 が同えることから，職業・年齢などの違いは，直接分析結 果には影響していないものと考えられる。

7 ）表 2 に示した環状線の利用状況別にサンプルを分けて分析 を試みたが，利用経験とイメージマップとの間には，何ら 関係性は見いだされなかった。

8 ) 居住年数とイメージの变形の程度（後述する真円度）との 関連性について謂べたが，両者間の相関はほとんど 0 に近 い値となった。詳しくは，文献 6 を参照されたい。

9）この分析は本研究を進める過程で追加的に行ったため，時 期的に最後に行ったりウル市での調查をもとにしている。 他の地域を対象とした確認作業は行っていないが，イメー ジマップの信頼性の確認だけの問題であるので，ソウル市 の例のみで充分であると判断した。
【文献リスト】

1) Kevin Lynch: The Image of the City, the Masachusetts Institute of Technology 1960 (丹下健三ほか共訳 : 都市 のイメージ，岩波書店，1968）

2) 三條明に: 東京の地下鉄網に対する認知構造に関する研究, 都市計画論文集, 27, pp. 283-288, 1992

3) 青木義次ほか : 都市の地理的イメージにおける認識フレー ムの影䇾一山手線イメージの円環的フレームによる変形一， 日本建築学会関東支部研究報告集 (計画系), pp. 193-196, 1989

4) 青木義次ほか: 地理的イメージにおける認識の模式図の影 響一山手線の円環状認識構造一, 日本建築学会大会学術講 演梗概集 (F), pp. 123-124, 1990. 10

5) 青木義次ほか: 地理的イメージにおける認識の模式図の影 響一大阪環状線の円環状認識構造一, 日本建筇学会関束支、 部研究報告集 (計画系), pp. 201-204, 1991. 1

6) 青木義次ほか : 都市の地理的イメージにおける認識の模式 図の影響一山手線及び大阪環状線の円環状認識構造一, 日 本建筑学会大会学衡撞演梗概集(F), pp. 161-162, 1991.9

7）青木義次ほか : 都市の地理的イメージにおける概念認識の 影響一㲦国ソウル市の 2 号線の諗識構造一, 日本建築学会 関東支部研究報告集（計画系), pp. 189-192, 1992.1

8）青木義次ほか : 地理的イメージにおける概念図形ーソウル 市環状 2 号線の認識構造一, 日本建筑学会大会学術講演便 概集(F), pp. 597-598, 1992. 8

9）青木義次ほか：地理的認識が避難行動に及ぼす影響一地震 時避数行動の情報伝達作用モデルの研究 その 4 -, 日本 建築学会大会学術講演梗概集 (F), pp. 399-400, 1991.9

10）青木義次ほか：情報伝聞と地理イメージ変形を考虑した震 時避難行動シミュレーションモデル，日本建筑学会計画系 論文報告集，第440 号, pp. 111-118, 1992.10

11）日本建築学会編：建筑・都市計画のための調查・分析方法， 井上書院, 1987

（1993 年 4 月 7 日原稿受理，1993 年 8 月 25 日採用決定） 